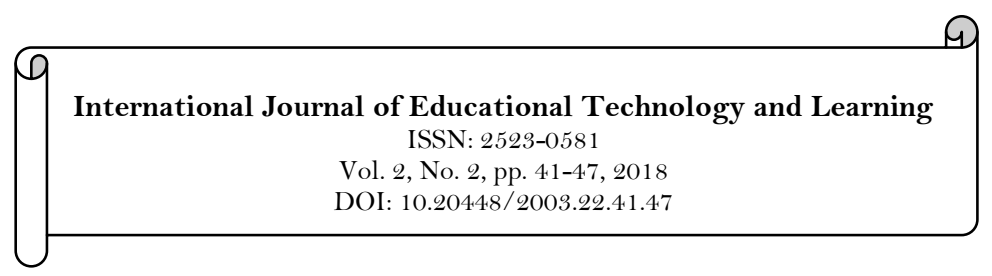

\title{
Effectiveness of PBL through Concept Map to Improve Problem Solving Skills of Primary School Students
}

\author{
Issufiah Dwi Nuryati ${ }^{1}$ \\ Sunardi ${ }^{2}$ \\ Sri Anitah W. ${ }^{3}$ \\ Gunarhadi $^{4}$ \\ ${ }^{1,2,3,4}$ Sebelas Maret University of Surakarta, Indonesia. \\ 'Email:suffy_dn@yahoo.com
}

\begin{tabular}{|c|c|}
\hline Abstract & \\
\hline $\begin{array}{l}\text { Effectiveness of PBL Through Concept Map to Improve Problem } \\
\text { Solving Skill of Primary School Students, } 2017 \text {. This research aims to } \\
\text { knowing the effectiveness of Problem Based Learning (PBL) through } \\
\text { concept maps as to improve problem solving skill for primary school } \\
\text { students. Research conducted in March-June } 2016 \text { at a primary school in } \\
\text { Surakarta The method in this research is the research experiments with } \\
\text { models of post test only control design. The study subjects consisted of } \\
\text { three schools as a control group and three schools as experimental } \\
\text { groups. Uji effectiveness using independent t-test to tell the difference } \\
\text { between a group test results mean experimental and control group. The } \\
\text { results of the independent t-test between experimental group and the } \\
\text { control group on three pairs of States that t count is larger than the } t \\
\text { table. The results of the independent t-test between eksperiment } 1 \text { and } \\
\text { control } 1 \text { tcalculate } 5.065>\text { table } t=2.000 \text {. The results of the independent } t- \\
\text { test between eksperiment } 2 \text { and control } 2 \text { tcalculate } 8.341>t_{\text {table }} 1.990 \text {. The } \\
\text { results of the independent } t \text {-test between eksperiment } 3 \text { and control } 3 \\
\text { shows } t_{\text {count }} 5.262>t_{\text {table }} 2.000 \text {. The third pair of shows there is a } \\
\text { significant difference between the group's experiments with the control } \\
\text { group, then the stated learning is more effective than with the learning } \\
\text { of problem solving. }\end{array}$ & $\begin{array}{l}\text { Licensed: } \\
\text { This work is licensed under a } \\
\text { Creative Commons Attribution } \\
\text { 4.0 License. } \\
\text { Publisher: } \\
\text { Scientific Publishing Institute }\end{array}$ \\
\hline
\end{tabular}

\section{Introduction}

Teaching and learning undertaken by teachers should put more emphasis on activities that explore and develop competencies that have been owned by students. It aims to prepare learners meet the challenges of globalization. The nation's children sued has the ability to communicate, clear, critical thinking, creative problem solving, have strong skills, become a citizen of a democratic, and accountable.

In the events of world level academic competitions, often losing compared to developing countries in the world. Average math and science achievement scores are still significantly below the international average score. Ina, Mullis, Martin, and Alka (2012). Tests in TIMMS and PISA emphasizes on how to think of creative thinking, reasoning, and problem solving. Indonesia cannot achieve achievement in the event because in not much learning leads to critical thinking skills and solve problems. During this time most of the learning of mathematics and science only in the level of basic skills math and memorizing the low level not much maximized on the efforts of reasoning and problem solving.

The problem in this research is how big the effectiveness of learning model of PBL through concept map in improving student ability in solving problem. This learning model for hoping to enrich the science education so that it can be applied by teachers, in order to be able to assist students in understanding the subject matter.

\section{Theoretical Review}

\subsection{Education in Primary School}

Education at the primary level is an early stage education of children after them through the early stages through the play in early childhood education. Early childhood education to prepare students who will be 
pursuing an education in the elementary school (Indriyanto, 2004).Education in primary base is aimed at laying the Foundation of intelligence, personality, attitudes, knowledge, and skills for independent living and following further education (RI Permendiknas No. 23/2006 standard of competence of graduates for the units of primary and secondary education)

Primary school education curriculum aims to develop the ability and penchant for reading, writing, numeracy skills, as well as the ability to communicate.

The curriculum is developed in primary schools should be emphasized at the formation of the following things: 1) literasy, refers to an understanding the learners about the different phenomenon in her environment in tailoring the behavior in life; 2) ability to communicate, that is, the ability of learners to understand the phenomenon in her environment and put it in the language of Indonesia; 3) ability of solving problems, which refers to the ability of the learners in the feel there is a problem, identify problems, find information to solve problems, explore alternatives to problem solving, and chose the most viable alternative, 4) reality ability, which refers to the ability of learners in using logic and evidence in system and consistently to arrive at conclusions (Wardani, 2009).

Primary School students' age ranges between 7 and 11 years. In Piaget's theory, this age is on concrete operational stage. Concrete operational thinking is a cognitive milestone enabling the students to think and to act just like what they do, and requiring concrete object to conceive a concept. Children can think more logically than that in previous age. Concrete operational period can do logical reasoning replacing intuitive reasoning through concrete examples (Santrock, 2010).

Generic competency the students should achieve includes three domains: affective (attitude), cognitive (knowledge), and psychomotor (skill). Affective domain is divided into two: spiritual and social attitudes. Graduation Standards (Permendikbud [Culture and Education Minister's Regulation] Number 21 of 2016) the Primary School students should achieve in spiritual dimension include: receiving, implementing, and appreciating the religion tenets they hold on. In social attitude domain, students can show off honest, discipline, decorous, self-confident, caring, and responsible behaviors in interacting with family, friend, teacher, neighbor, and state. Knowledge dimension includes conceiving factual, conceptual, procedural and metacognitive knowledge at basic level by means of: observing, questioning, and trying based on curiosity on themselves, God's creatures and their activity, and objects found at home, at school, and in the playground. Skill dimension includes the abilities of thinking and acting creatively, productively, critically, independently, collaboratively, and communicatively in clear, systematic, logical, and critical language in esthetic work, in the movement reflecting on healthy children and action reflecting on the children's behavior corresponding to their development stage.

As the attempt of mastering several attitude, knowledge, and skill dimensions, a scientific learning should be created that can involve the students to be active and creative, and to think critically and joyfully. Such the learning models include PBL, Project Based Learning, Discovery, and Inquiry Learning.

\subsection{Problem Based Learning (PBL)}

The essence of PBL, according to Howard S. Barros in Kek and Huijser (2017) includes, among others, 1) authenticity, 2) problems should present as they do in the real world and permit free inquiry by learners , 3) problems should present as they do in the real world and permit free inquiry by learners , 4) student-centered, 5) Self-directed learning skill development , 6) integrated knowledge, 7) small group collaborative learning, 8) reiterative , 9) reflective, skilled tutors, 10) foundational. The success of PBL is not only limited to its learning process, but is also supported with curriculum foundation, learning material, teachers committed to managing the learning, and students' persistence and cooperation in collaboration.

Problem based learning focuses on the problem given to the students so that problem solving process occurs, and cooperation is often conducted in small groups to find solution (Wurdinger \& Rudolph, 2009). PBL emphasizes on the problem as the starting point of learning process. This PBL is a constructivist approach with many advantages (Kartikasari \& Widjajanti, 2017).

The theoretical foundation of PBL is collaboration considered as capable of practicing the students to express their opinion, to build reasoning on knowledge they have, and all acquisitions as the result of activities in interacting with others (Firdaus, Wahyudin, \& Herman, 2017). With regard to relatedness for collaboration, student having the opportunity to talk with and socialize with their peers and feeling a sense of community are important aspects of school for many students (Dole, Bloom, \& Doss, 2017).

PBL requires the students to be responsible for identifying problem, observing their choice, and formulating solution (Tillman, 2013). The problem solving in PBL uses scientific method involving: problem definition, brainstorming process, hypothesis development, simple research, discussion about phenomenon obtained from the result of observation, and conclusion drawing as the solution to the problem (Yaqinuddin, 2013). Meanwhile, in teaching using scientific method, teachers should encourage the students to develop better understanding in the research, even if possible teachers should present the scientific methodology as well as possible (Keyes, 2010). 
The principles of PBL are as follows: student-oriented learning, problem serving as starting point, working in group with peer, problem solving sought for from many sources, and students collecting information and knowledge from real life independently (Tillman, 2013). Hung (2013) highlights the practical dynamic of PBL as the learning method preparing the students to solve problem in the context of real world the students find easily.

The problem solving process is conducted by collecting information and processing it in order to be the solution to the problem studied. The information collecting process should be organized through planned process, thinking, discussing, reviewing information and communicating (Baysal, 2017).

Through PBL gives the students the opportunity as wide as possible to try finding something new. PBL as the constructivism-based learning strategy is a concept in which the students construct their own conception by connecting concrete experiences to acquire new knowledge through collaboration and reflection process (Ajai, ImokoI, \& O'kwu, 2013).

The students will learn from the existing events in surrounding environment, thereby can create and modify their conception on reality surrounding. One instrument of collecting, organizing, and processing information from surrounding world to solve problem is to have scientific process skill (Zoldošová \& Matejovicová, 2010) and the students should conduct the activity directly (Rozhana \& Firdiastuti, 2017).

In contrast to conventional learning, in PBL students can organize their thinking orderly and it is very important to help solve the problem (Ajai et al., 2013).

Wynn and Okie (2017) has proved that PBL as an ideal instructional method practices collaborative and deliberative skill, and effective conclusion drawing skill. Roopashree (2014) states that the learning cycle using PBL model is as follows: it starts with the problem given to students, conducting experiment or data collecting activities, identifying the concepts to master in order to solve problem, assembling again to have discussion and to share experience learnt, and determining solution collaboratively with their peer in group. The problem-solving and learning process, PBL students collaborate to solve the problem and learn in small groups. This collaboration component is to help students develop social, interpersonal, collaborative. In this learning environment, students are acculturated to practice these skills and ultimately internalize them into their fundamental dispositions toward learning (Hung, 2013).

\subsection{Concept Map}

A concept mapping facilitates strongly the meaningful learning. Concept map helps the students consolidate their conception on knowledge they have learnt and practice their problem solving ability (Sun \& Chen, 2016). Students' conception on the learning outcome through task (assignment) and inquiry can be summarized into concept map, so that the learning can run more effectively and efficiently (Chichekian \& Shore, 2013). The learning with concept map helps focus attention and understand the concepts of knowledge. General knowledge can be studied by elaborating it into more detailed concepts, in order to be more understandable to the students (More, Williams, Nort, Johri, \& Paretti, 2015).

There are several stages in developing a Novakian concept map (Davies, 2011).

a. Develop a declarative-type focus question (e.g., "What is inflation?")

b. Devise a "parking lot" of concepts and ideas that are related to the concept of inflation, and the question to be answered. The purpose of this stage is brainstorming. The concepts are placed in circles or boxes to designate them as concepts.

c. Put concepts in hierarchical order of importance in a provisional map. An "expert skeleton map" can be started by an instructor in a class to scaffold the learning process, aid student participation and give students confidence. Students can complete the map themselves with the focus question and concepts provided.

d. Link lines are then provided between the hierarchical concepts from top to bottom. The conventions have changed over the decades since the inception of concept mapping. Arrows were originally only used when it is necessary to link a lower concept with a higher concept. Devise suitable cross-links for key concepts in the map. Verbs and prepositions/prepositional phrases are used most frequently, for example: "requires", “to work with", "will lead to", “involves", “during”, “of", "through”, and so on. The aim is to show the relationship between the key concepts and their subordinate or superordinate elements.

e. Add examples to the terminal points of a map representing the concepts. These are not enclosed in boxes or circles to delineate them as instances of a concept.

\subsection{Concept of Problem Solving}

Critical thinking skills in giving the right direction in thinking and work, and assist in determining the interconnectedness of things with the other with a more accurate.

The ability of critical thinking is urgently needed in the problem solving/search solutions, and project management. The development of critical thinking ability is the integration of some parts of development capabilities, such as observations, analysis, reasoning, judgment, decision-making, and persuasion. The better development of these skills, then we will be increasingly able to overcome problems with satisfactory results. 
According to Polya (1985) problem solving as a business seeking a way out of a difficulty to achieve a purpose which is not immediately achievable.

D'Zurilla and Nezu (2001) defined as the process of solving cognitive behavioral self help where someone tried to identify or find an effective solution to a particular problem and adaptive encountered in everyday life. Problem solving can also be interpreted as measures to overcome the gaps, while the activity of problem solving itself is a human activity in applying the concepts and the rules that obtained previously (Dahar, 1998).

\section{Method}

This research was conducted in three primary schools in the city of Surakarta, that school of Serengan II, Kemasan II, and Slembaran. Research time in Mater-June 2016. This type of research is experimental models of post test only control design.

Three schools as an experimental group and three schools as a control group Experimental group were given preferential treatment by the model of PBL through concept maps, while the control group with the model of problem solving. Data processing with different test endependent $t$-test. Prior to test $t$, first performed its homogeneity and normality test.

\section{Research Results}

\subsection{The Results of the Analysis of the Experimental Group 1 and the Control Group 1}

One of the prerequisites for the independent t-test test, done and test the normality of its homogeneity. Test results of its homogeneity, normality, and knowing the level of significance was done with SPSS such as indicated in the following table.

The table below shows the test result one pair experiment group 1 and the control group 1 namely school of Kemasan with Bunderan.

Table-1. Independent t-test experimental group 1 and the control group 1

\begin{tabular}{|c|c|c|c|c|c|c|c|c|}
\hline Group & $\mathbf{N}$ & Mean & SD & Nor-mality & Homo-genity & DF & $\mathbf{T}$ & Sign. \\
\hline $\begin{array}{l}\text { Kemasan } \\
\text { (Experimental) }\end{array}$ & 24 & 71.33 & 10.52 & $\begin{array}{l}0546 \\
(p>0.05)\end{array}$ & \multirow[t]{2}{*}{$\begin{array}{l}0818 \\
(p>0.05)\end{array}$} & 57 & 5,065 & $0000^{*}$ \\
\hline $\begin{array}{l}\text { Bunderan } \\
\text { (Control) }\end{array}$ & 35 & 57.09 & 10.67 & $\begin{array}{l}0437 \\
(p>0.05)\end{array}$ & & & & \\
\hline
\end{tabular}

Table 1 shows the count test normality distribution data show that both group is normal with the $\mathrm{p}$ of 0,546 greater than $0.05(\mathrm{p}>0.05)$ to experimental group 1 and $\mathrm{p}$ of $0,437(\mathrm{p}>0.05)$ tothe control group 1. Both of these groups revealed normal data. Next done test of its homogeneity, obtained the results that this research subject in homogeneous, with the $\mathrm{p}$ of 0,818 greater than $0.05(\mathrm{p}>0.05)$. The next test is done hipotesis with independent t-test. The results of the independent $t$-test between eksperimen group 1 and control group 1 of $0,000<0.05$ with $t_{\text {calculate }}=5.065$ and $t_{\text {table }}=2.000$. The results of the experimental group was declared $t_{\text {calculate }}$ greater than $t_{\text {table }} 0.05 \quad\left(t_{\text {calculate }}>t\right.$ table). This shows that there is a significant difference between both eksperiment group 1 and control group 1.

\subsection{The Results of the Analysis of the Experimental Group 2 and the Control Group 2}

The second test in this study is to group the second experimental group i.e. couples from SDN Serengan with a control group of SD Al Islam 2 Jamsaren. Test the independent t-test for experimental group 2 and control group 2 can be seen in Table 2 .

Table-2.Independent t-test Experimental Group 2 and control group 2.

\begin{tabular}{l|c|c|c|l|l|l|l|l}
\hline Group & N & Mean & SD & Nor-mality & Homo-genity & DF & t & Sign. \\
\hline $\begin{array}{l}\text { Serengan } \\
\text { (Experimental) }\end{array}$ & 35 & 83.06 & 9.23 & $\begin{array}{l}0190 \\
(\mathrm{p}>0.05)\end{array}$ & $\begin{array}{l}0551 \\
(\mathrm{p}>0.05)\end{array}$ & 8,341 & $0000 *$ \\
\hline $\begin{array}{l}\text { Al Islam } 2 \\
\text { Control })\end{array}$ & 39 & 65.69 & 8.67 & $\begin{array}{l}0927 \\
(\mathrm{p}>0.05)\end{array}$ & & \\
\hline Note: ${ }^{\mathrm{p}<0.05}$
\end{tabular}

Table 2 shows that thethe mean of experimental group 2 of 83.06 while the control group mean 2 of 65.69. Test results showed normality distribution data of both groups are normal with the p of 0,190 ( $p>$ 0.05) to experimental group 2 and $\mathrm{p}$ of $0,927(\mathrm{p}>0.05)$ for the control group 2 . Furthermore based on test results obtained by its homogeneity that subject in research is homogeneous, with the p of $0,551(\mathrm{p}>0.05)$. Because requirements are met furthermore conducted a test of the hypothesis using independent $t$-test. The results of the independent $t$-test between eksperiment group 2 and control group 2 of $0,000<0.05$ with $t_{\text {calculate }}=$ 8.341 and $t_{\text {table }}=1.990\left(t_{\text {coun }}>t_{\text {table }}\right)$ shows that there is a significant difference between the eksperiment group 
2 and control group 2. Because $t_{\text {count }}>t_{\text {table, }}$, then there is a significant difference between the mean of the test results experimental group with the control group.

\subsection{Experimental Group 3 and the Control Group 3}

Test the independent $t$-test for the experiment group 3 and the control group 3 can be seen in Table 3 below.

Table-3. Independent t-test experimental group 3 and the control group 3

\begin{tabular}{l|l|l|l|l|l|l|l}
\hline Group & N & Mean & SD & $\begin{array}{l}\text { Nor- } \\
\text { mality }\end{array}$ & $\begin{array}{l}\text { Homo- } \\
\text { genity }\end{array}$ & DF & t \\
\hline $\begin{array}{l}\text { Slembaran } \\
\text { (Experimental) }\end{array}$ & 41 & 76.78 & 5.04 & $\begin{array}{l}0470 \\
(\mathrm{p}>0.05)\end{array}$ & $\begin{array}{l}\text { Sooo } \\
(\mathrm{p}>0.05)\end{array}$ & 69 & 5,262 \\
$\begin{array}{l}\text { Danukusuman } \\
\text { Control) }\end{array}$ & 30 & 65.53 & 12.38 & $\begin{array}{l}0832 \\
(\mathrm{p}>0.05)\end{array}$ & $0000 *$ \\
\hline
\end{tabular}

Table 3 shows that the mean test results experiments group 3 of 76.78 , where as the mean test results from a control group 3 of 65.53. From these data it appears that there is a difference of mean test results from experiments with conrol group test results mean. The second data distribution groups are normal with the $\mathrm{p}$ of $0,470(p>0.05)$ to experimental group 3 and $p$ of $0,832(p>0.05)$ for the control group 3. Furthermore based on test results obtained by its homogeneity that subject in research is not homogeneous, with the $p$ of $0,000(\mathrm{p}<0.05)$.

According to (Azwar, 2001) an analysis of the difference can be done without having to do the inspection in advance against the respective assumptions are not fulfilled, such as the assumption of normality and its homogeneity. If the respondent research is already quite a lot, then the assumption of normality is not unduly influence the results of the analysis. So was assuming its homogeneity, this assumption can also be ignored without a large risk for respondents in both groups amounted to relatively the same.

From those results can proceed on the hypothesis test usingindependent t-test. The results of the independent $t$-test between eksperiment group and control gorup 3 the test results showed that $t$ of $0000<0.05$. The result $\mathrm{t}_{\text {calculate }}=5.262$ compared to table $\mathrm{t}=2.000$, then $\mathrm{t}_{\text {calculate }}=5.262$ is larger than the $\mathrm{table}_{\mathrm{t}} \mathrm{t}=2.000\left(\mathrm{t}_{\text {calculate }}>\mathrm{t}_{\text {table }}\right)$. It can be di interpretation that there is a significant difference between the both eksperiment group 3 and control group 3.

The results of the Independent $t$-test the third pair/group that each value $t_{\text {calculate }}$ is greater than $t_{\text {table }}\left(t_{\text {calculate }}\right.$ $\left.>t_{\text {table}}\right)$, so that there is a significant difference in the mean results of the experimental group with control group.

\section{Discussion}

T test results on a pair of experimental group 1 and the control group 1 is the school that has almost the same standard. The condition of the characteristics and background of the students is also almost the same. The two schools simultaneously given the same material with different treatment during three meetings. After being given the post test for three times, the experimental group gets an mean 63.95; 73.13; and 76.87, if on average be 71.33 .

If seen from the treatment for three times, increasing student achievement. It can be assumed that learning is applied in the classroom the more acceptable by students and teachers more clever in applying this model. The results of the control group in this couple was also given the same test three times, but his education with problem solving. The mean test results is 64.14; 47.29; and 59.85, if on average becomes 57.09. Regardless of the statistics independet t-test it appears that mean far higher experimental group compared to the control group mean.

As well as the results of the experimental group 1 pair, test results from the experimental group pairs 2 and 3 also show nearly the same results. Couples experiments group 2 and 3 is a partner school with almost the same standard. Mean of 2 and 3 is also an increase in student achievement test results of the meeting of 1 , 2, and 3. Experimental group test results mean 2 of three times the meeting was 83.06, where as the control group 65.69 mean. It seems clear that there is a difference in test results. Mean test results than experimental group 3 and control group 3 is 76.78 with 65.53. There are also groups of 3 couples difference mean test results.

The effectiveness of PBL learning model through concept map is supported by student maturity process. Through regular and continuous training, students' ability to solve problems will be more honed. As Jean In PBL students can organize their minds in an orderly manner that is essential to help problem solving (Ajai et al., 2013). Wynn and Okie (2017) have proven that PBLs are an ideal instructional method, practicing collaborative, deliberative, and effective decision-making skills. 
Whimbey, Lochhead, and Narode (2013) that an effective way to improve problem-solving skills for students is to work with friends, think hard, learn from each other, and look back at previous problems that are almost identical to the problem. (Baysal, 2017) PBL is able to generate student motivation to learn, students learn to make connections with real life, gain concrete knowledge, can exchange information, think critically, students have confidence, practice language skills, and trained students to spend time effectively.

\section{Summary}

A summary of this research is that learning with PBL models through concept maps by students followed by enthusiastic, fun, train students to learn to think critically, creatively, and independent. PBL models through to concept maps proved to be more effective than the learning model of problem solving.

PBL models through this concept map has advantages, such as: a) train students to perform observation, experiment, and solve simple problems encountered in the environment, b) train students to cooperate in discussion activities, c) train students to dare argue and communicate through discussions and presentations, d) train students to assess the results of the study for either him self or the assessment between friends , e) learning with concept maps very help students to understand the concepts learned and trained to think critically of the existing concept of linking with the other fields.

\section{References}

Ajai, J. T., ImokoI, B., \& O'kwu, I. (2013). Comparison of the learning effectiveness of problem-based bearning (PBL) and conventional method of teaching algebra. Journal of Education and Practice, 4(1), 131-136.

Azwar, S. (2001). Research method. Yogyakarta: Student Literature.

Baysal, Z. N. (2017). The problem-based learning process: Reflections of pre-service elementary school teachers. Academic Journals, 1(4), 177-188. Available at: 10.5897/ERR2016.3045.

Chichekian, T., \& Shore, B. M. (2013). Concept maps provide a window onto preservice elementary teachers' knowledge in the teaching and learning of mathematics. Canadian Journal of Education, 36(30), 47-71.

D’Zurilla, T. J., \& Nezu, A. M. (2001). Problem solving therapies. In K.S. Dobson (Ed.), Handbook of cognitive-behavioural therapies (2nd ed.). New York: Guilford Press.

Dahar, R. W. (1998). Learning theories. Jakarta: Depdikbud - Directorate General of Higher Education.

Davies, M. (2011). Concept mapping, mind mapping and argument mapping: What are the differences and do they matter? Higher Education, 62(3), 279-301 Available at: 10.1007/s10734-010-9387-6.

Dole, S., Bloom, L., \& Doss, K. K. (2017). Engaged learning: Impact of PBL and PjBL with elementary and middle grade students. Interdisciplinary Journal of Problem-Based Learning, $11(2), 9$.

Firdaus, F. M., Wahyudin, \& Herman, T. (2017). Improving primary students' mathematical literacy through problem based learning and direct instruction. Academic Journals, 12(4), 212-219.

Hung, W. (2013). Problem-Based Learning: A learning environment for enhancing learning transfer. New Directions for Adult and Continuing Education, 2013, 27-38. Available at: 10.1002/ace.20042.

Ina, V. S., Mullis, M. O., Martin, P. F., \& Alka, A. (2012). Timss 2011 international results in mathematics. USA : TIMSS \& PIRLS International Study Center, Lynch School of Education, Boston College.

Indriyanto, B. (2004). Early childhood education: Discrete and discrete phase demarcation in child development, Early Childhood Bulletin, Dirjen (pp. 46-69). Diklusepa: Special Edition.

Kartikasari, A., \& Widjajanti, D. B. (2017). The effectiveness of problem-based learning approach based on multiple intelligences in terms of student's achievement, mathematical connection ability, and selfesteem. Journal of Physics: Conf. Series, 812(1), 12097.

Kek, M. Y. C. A., \& Huijser, H. (2017). Problem-based learning into the futute. Singapore: Springer.

Keyes, G. (2010). Teaching the scientific method in the social sciences. Journal of Effective Teaching, 10(2), 18-28.

More, J., Williams, C., Nort, C., Johri, A., \& Paretti, M. (2015). Effectiveness of adaptive concept maps for promoting conceptual understanding: Findings from a design-based case study of a learner-centered tool. Advances in engineering education. Sumer 2015. 1-35.

Polya, G. (1985). How to solve it. Princeton: Princeton University Press.

Roopashree, B. J. (2014). PBL: Future challenges for educational practice and research. Journal on School Educational Technology, $10(2), 9-16$.

Rozhana, K. M., \& Firdiastuti, H. R. (2017). The model of problem based instruction is assisted by mind mapping in material social problems in the local environment to improve the activities and learning outcomes of fourth grade elementary school students. Nusantara Basic Education Journal, 2(2), 198-204.

Santrock, J. W. (2010). Life-span development (13th ed.). New York: McGraw-Hill.

Sun, J. C. Y., \& Chen, A. Y. Z. (2016). Effects of integrating dynamic concept maps with Interactive Response System on elementary school students' motivation and learning outcome: The case of anti-phishing education. Computers $\mathcal{E}^{\circ}$ Education, 102, 117-127.

Tillman, D. (2013). Implications of problem based learning (PBL) in elementary schools upon the K-12 engineering education pipeline. The University of Texas at El Paso (UTEP). Conference \& Exposition (2013) Papaer ID \#7729. 1-14.

Wardani. (2009). SD education perspective. Jakarta: Open University.

Whimbey, A., Lochhead, J., \& Narode, R. (2013). Problem solving and comprehension (7th ed.). New York: Routledge.

Wurdinger, S., \& Rudolph, J. (2009). Teaching practices that improve student learning: Five experiential approaches. Journal of Teaching and Learning, 6(1), 1-13. 
Wynn, C. T. S., \& Okie, W. (2017). Problem-Based Learning and the training of secondary social studies teachers: A case study of candidate perceptions during their field experience. International Journal for the Scholarship of Teaching and Learning, $11(2)$.

Yaqinuddin, A. (2013). Problem-based learning as an instructional methot. Journal of the College of Physicians and Surgeons Pakistan, 23(1), 83-85.

Zoldošová, K., \& Matejovicová, I. (2010). Finding out how the elementary school children manipulate with empirical material and how they process the obtained information. International Electronic Journal of Elementary Educatio, $2(3), 327-347$. 